\title{
A Survey on Clinical Observation in Graduate Schools
}

\author{
Hwa Young Pyo \\ Department of Speech-Language Pathology, College of Health Science, Chosun University, Gwangju, Korea
}

Correspondence: Hwa Young Pyo, PhD Department of Speech-Language Pathology, College of Health Science, Chosun University, 309 Pilmun-daero, Dong-gu, Gwangju 61452, Korea Tel: +82-62-230-6188

Fax: +82-62-230-6271

E-mail: entvoice@chosun.ac.kr

Received: April 5, 2017

Revised: May 15, 2017

Accepted: May 18, 2017

This study was supported by research fund from Chosun University, 2014

\begin{abstract}
Objectives: The present study was performed to investigate the actual conditions of clinical observation for the students of Departments of Speech-Language Pathology (SLP) in graduate schools, and to find how to improve them. Methods: Questionnaires on the clinical observation in graduate schools were distributed by e-mail as an online survey to the faculty and staff in charge of clinical observation in graduate schools; 25 of 27 schools responded to the survey. Results: Twenty of the responding schools utilized clinical observation. Most of the schools lowered the observation requirements when the trainee's major in undergraduate school was SLP or the trainee had an SLP certificate. Direct observations were conducted more than indirect observations. Institutes offering observations were private clinics, speech therapy clinics attached to hospitals, welfare centers for the disabled, and multicultural family support centers. Most speech-language pathologists offering observations had a level 1 certificate and had been working for 5 to 10 years. Trainees usually had opportunities to meet patients with various kinds of communication disorders. Many schools had difficulty in looking for institutes to offer appropriate observation practices and arranging the observation schedules. Conclusion: Every school tries to give trainees opportunities to meet patients with various types of communication disorders in different settings. To improve the actual conditions of clinical observation, academies and associations for SLPs should try to find appropriate and efficient support networks beyond the graduate schools themselves.
\end{abstract}

Keywords: Clinical observation, Speech-language pathology, Graduate school, Survey
2011년 8월 4일 개정된 장애인복지법 7장 '장애인 복지 전문인력' 중 제 71 조 1 항에는 "국가와 지방자치단체 그 밖의 공공단체는 의 지.보조기 기사, 언어재활사, 장애인재활상담사, 한국수어 통역사, 점역 교정사 등 장애인 복지 전문인력, 그 밖에 장애인 복지에 관한 업무에 종사하는 자를 양성·훈련하는 데에 노력해야 한다"(National Law Information Center, 2017a)는 내용이 포함되어 있다. 이에 근거하여 1년 뒤인 2012년 8월 5일에 언어재활사의 국가자격증 제 도가 정식으로 시행되었다. 이전에 한국언어장애전문가협회에서 운영하던 대로 언어재활사의 국가자격증은 1 급 및 2 급 두 개의 급 수를 유지하게 되었으나 1 급 자격증 취득 조건은 이전과 달라졌다. 한국언어장애전문가협회에서 1 급 자격증 취득 조건으로 "1. 협회 가 인정하는 국내외 대학원에서 언어치료학 석사 이상의 학위를 취
득한 사람", "2. 협회가 시행하는 언어장애전문가 2급 자격증 시험 (이하 “2급 자격증시험”이라고 한다)에 합격한 사람(이 항목은 2007년도 입학생부터 적용)"이라는 조건을 모두 충족하도록 했다 (Korean Association of Speech-Language Pathologists, 2017). 그러 나 현행 장애인복지법 제 75 조의 2 (언어재활사 자격증 교부 등)의 2 항에 명시된 1 급 자격증 취득자격으로는 " 2 급 언어재활사 자격증 을 가진 사람으로서 다음 각 목의 어느 하나에 해당하는 사람. 가. 「고등교육법」에 따른 대학원에서 언어재활 분야의 박사학위 또는 석사학위를 취득한 사람으로서 언어재활기관에 1년 이상 재직한 사람. 나. 고등교육법」에 따른 대학에서 언어재활 관련 학과의 학사 학위를 취득한 사람으로서 언어재활기관에 3년 이상 재직한 사람" 으로 명시하여 이전 협회의 규정과 달리 대학원 졸업을 1 급 자격증 
취득의 필수조건이 아닌 선택조건으로 두었다(National Law Information Center, 2017a).

2 급 자격증 취득 후 대학원을 졸업하지 않아도 1 급 자격증을 취 득할 수 있게 되었기 때문에 언어치료(재활)학과의 학부 과정은 필 히 언어재활사자격증 취득을 목표로 한 교육과정을 수립하고 있는 반면 대학원 과정은 학교 상황, 학생 상황에 따라 보다 더 유동적인 교육과정 수립이 가능하게 되었다. 이중 학교마다 큰 차이를 보이게 된 것 중 하나가 언어임상관찰 및 언어임상실습 등 임상실습과목이 다. 장애인복지법 시행규칙 중 별표 6 의 2 는 제 57 조의 4 (언어재활 관련학과 등) 중 2항에 따른 언어재활 관련 교과목으로 필수과목 10 개, 선택과목 23 개를 제시하고 있는데 언어재활관찰, 언어진단실 습, 언어재활실습, 언어재활현장실무는 필수과목에 포함되어 있다 (National Law Information Center, 2017b). 다른 필수과목은 이론 과목으로서 임상뿐 아니라 연구를 위해서도 중요하므로 대부분의 (거의 모든) 대학원에서 필수 이수과목으로 지정하고 있으나 임상 실습관련 과목은 상황에 따라 다양하게 교육과정을 운영하고 있다.

언어치료학은 언어치료 전반에 대해 학문적으로 연구하는 분야 이고 언어치료는 의사소통장애 문제를 갖고 있는 사람을 대상으로 평가 및 중재를 수행하는 업무를 지칭하기 때문에 언어치료학은 임 상실제, 임상현장과 불가분의 관계를 갖는다. 그러므로 언어치료학 을 공부하는 사람에게 임상실제는 연구를 우선으로 하는 대학원 과정의 재학생이더라도 대학원 과정에서든 학부 과정에서든 반드 시 경험해봐야 하는 내용이다.

이론적 지식을 충분히 갖고 있다고 해도 이를 직접 임상현장에 적용하기는 쉽지 않다. Kim과 Shin (2015)은 언어치료전공 학생들 의 임상실습 만족도를 조사한 결과 수강한 이론을 실습에 적용하 는 항목에서 만족도가 매우 낮게 나타났다고 했다. 이는 언어치료 뿐 아니라 모든 임상계열 종사자들의 공통된 과제이다. 간호대학생 들은 임상실습 과정 중 새로운 환경과 예상하지 못한 문제, 간호대 상자 및 의료인과의 관계에서 어려움을 경험한다고 했다(as cited in Koo \& Im, 2013). 또한 이들은 임상에서 이론과 실습 간의 차이 로 인한 혼란 등으로 많은 어려움과 스트레스를 겪는다고 했다(as cited in Kim, Kim, Song, Ahn, \& Chae, 2004).

우리나라에서는 대략 2000년대 후반부터 언어치료학과의 임상 실습에 대한 연구논문이 발표되기 시작했다. Kim과 Lee (2009)는 언어치료학과의 임상실습 교육 현황을 파악하여 그에 근거한 임상 실습교육모형을 제안했다. Kwon 등(2010)은 2007년에 한국언어치 료전문가협회 및 전국언어치료학과협의회가 보고한 언어치료학과 학과인증제 연구를 정리한 학술지 논문에서 언어치료학과 학부 및 대학원의 임상실습 현황을 보고했다. Hwang, Choi, Kim과 Lee
(2012)는 언어재활과 재학생 및 졸업생들을 대상으로 임상관찰 및 치료실습에 대한 만족도 조사를 실시했고, Kim과 Shin (2015)은 언 어치료전공 학생들의 임상실습 만족도 및 교수효율성에 대한 연구 결과를 보고했다. Kim과 Lee (2015)는 언어재활전공 학생들과 임 상감독자를 대상으로 언어임상관찰을 위한 선수교과에 대한 연구 를 진행했다. Lee, Park과 Park (2015)은 언어재활과 학생들이 실습 시 경험하는 자기효능감과 실습불안에 대한 연구에 대해 보고하여 실습생들이 경험하는 심리적 갈등으로 그 관심 영역을 넓혔다. 그러 나 이 연구들은 대개 학부 재학생을 중심으로 한 연구들로서 대학 원 재학생을 대상으로 한 연구는 극히 드물다. 이미 30 개에 가까운 언어재활 관련 대학원 과정이 생겨 운영되고 있는 현 시점에서 대 학원에서 임상관련 실습이 어떤 식으로 진행되고 있는지 파악해야 할 필요성은 나날이 증가하고 있다.

이에 본 연구자는 대학원 석사과정 재학생을 대상으로 이루어지 고 있는 언어재활관찰실습(이하, 관찰실습) 제반의 현황을 파악하 는 설문연구를 진행하였다. 이를 통해 현재 대학원에서 이루어지는 언어재활관찰실습의 현주소를 파악하고 이를 토대로 언어재활관 찰실습의 개선을 위해 어떤 것이 필요한지 알아보고자 하였다.

\section{연구방법}

본 연구는 대학원 내 개설된 언어치료학과의 관찰실습 담당교원 에게 석사과정 재학생에게 시행되고 있는 관찰실습 현황에 대한 온라인 설문조사를 실시함으로써 진행되었다.

\section{연구대상}

본 연구는 대학원이 개설되어 있는 언어치료학과에 소속되어 석 사과정의 관찰실습을 담당하고 있는 교원을 대상으로 이루어졌다. 한국언어청각임상학회, 한국언어치료학회, 한국언어재활사협회 홈페이지에서 전국 언어치료학과 중 대학원 석사과정이 개설되어 있는 학교를 검색한 결과 총 27 개교로 파악되었다. 지역별로 보면 서울지역 3 개교, 경기지역 5 개교, 충남지역 2 개교, 대전지역 2 개교, 전북지역 2 개교, 전남지역 2 개교, 광주지역 5 개교, 경북지역 3 개교, 부산지역 2 개교, 강원지역 1 개교가 개설되어 있었다. 이 27 개교 소 속의 관찰실습 담당교원에게 온라인 설문지를 배포하였고 이중 25 개교에서 설문 응답을 회수하였다.

\section{실험방법}

설문지 작성

설문지를 구성할 문항 작성을 위해 현장실습 현황에 대해 설문 
조사를 실시한 선행문헌을 참고하였다. 언어치료학과(Kim \& Lee, 2009; Kim \& Lee, 2015; Kim \& Shin, 2015; Kwon et al., 2010; Lee et al., 2015; Hwang et al., 2012) 외에도 가정교육학과(Park, 2000), 간 호학과(Lee SE, 1997; Lee et al., 2002; Lee, Kim, \& Kim, 2004; Song \& Kim, 2013), 물리치료학과(Kim et al., 2004), 보건계열(Lee SJ, 1997), 식품영양학과(Yoon, So, \& Namkung, 1989), 안경광학과(Lee, Shin, \& Jung, 2010), 작업치료학과(Kim \& Kang, 2004; Lee et al., 2004), 치기공학과(Lee, Bae, \& Park, 2005). 특수교육학과(Kim, Park, Lee, \& Yoo, 2007; Yoo \& Kim, 2009)의 실습 현황을 조사한 선행연구 중 다수 연구에서 반복적으로 제시된 질문을 선별하여 총 25 문항으로 구성된 1차 설문지를 작성하였다.

이렇게 작성된 1차 설문지를 대학원 언어치료학과에 재직 중인 전임교원 2 인에게 전달하여 설문지의 타당성을 검증하도록 했다. 이들은 평균 12 년의 임상 및 임상실습 지도경력을 갖고 있으며 현 재 대학원 석사과정의 임상실습을 관리하고 있다. 2 회에 걸친 각자 의 단독 검증을 통해 2 차 수정본을 작성하였고 이를 본 연구자와 같이 논의하였다. 최종적으로 다른 문항에 비해 주관적인 답변을 요하는 3 개 문항을 문항의 통일성을 위해 삭제한 후 최종 22 개 문 항의 설문지를 완성하였다. 최종 설문 내용은 Appendix 1에 제시되 어 있다.

\section{설문지 배포}

설문지 작성은 네이버 폼 설문조사를 이용하여 이루어졌다. 이 설문지를 2017년 3월부터 4월까지 전자우편을 통해 대학원 석사과 정이 개설된 언어치료학과 소속 전임교원에게 배포하였다. 한 학과 당 관찰실습을 담당하고 있는 교원 한 명만 응답하도록 하였으며 한 학과 내에 두 개 이상의 대학원 과정이 있는 경우(예: 일반대학 원과 특수대학원이 둘 다 개설되어있는 경우) 두 개 이상의 과정에 서 관찰실습 진행에 차이가 없을 때는 하나의 응답을 보내도록 했 고 차이가 있을 때는 별도로 복수의 응답을 보내도록 했는데 관찰 실습을 진행하는 내용은 과정상의 큰 차이가 없는 것으로 파악되 었다. 안내문을 통해 해당 학과의 개별정보는 공개되지 않음을 알 려주었다.

\section{분석방법}

최종 회수된 25 개교의 응답 내용을 분석대상으로 하였다. 일반 적으로 설문조사를 실시할 때 연구내용을 알고 있는 대상자의 응 답은 제외하나 대학원이 개설된 언어치료학과의 총수 자체가 매우 적으므로 타당도 분석을 도운 2 인의 전임교원이 속해있는 학과 및 본 연구자의 학과에 대한 응답도 포함시켰다. 확보된 응답에 대해
서는 빈도 분석을 통해 빈도수 및 백분율을 구하였다.

\section{연구결과}

\section{배경정보}

설문에 응한 대학원 25 개교 중 일반대학원에 속해있는 학교는 9 개(36\%), 특수대학원에 속해있는 학교는 15 개교(60\%)였고 1개교는 이에 대해 응답하지 않았다. 언어치료학과가 소속된 특수대학원으 로는 보건대학원, 보건복지대학원, 보건보완의학대학원, 특수교육 대학원, 사회교육대학원, 재활과학대학원, 보건경영대학원, 보건 상담정책대학원, 사회개발대학원, 재활복지대학원, 교육대학원, 특수치료대학원 등 매우 다양하게 나타났다.

학과가 소속된 계열로는 인문사회계열이 9개(36\%), 자연계열이 10 개(40\%), 기타가 4 개(16\%)였고 응답하지 않은 학교가 2 개였다. 기 타로 기록한 계열은 보건계열이 2 개, 사범계열이 2 개였다.

대학원 석사과정 재학생 중 학부 전공자의 비율은 Figure 1과 같다. 그림에서 보는 것과 같이 '학부 전공자가 전체 중 $30 \%$ 이하('전혀 없는 것은 아니나 비전공자보다 훨씬 적은 편이다')'인 경우가 8개 (33\%)로 가장 많았으며 두 번째로 많은 경우는 '전체에서 $71 \%$ 이상 ('모두는 아니나 비전공자보다 훨씬 많은 편이다')'인 경우로 6개 (24\%) 학교가 응답했다. 학부 전공자가 $50 \%$ 인 경우를 기준으로 했 을 때 그를 초과하는 경우가 12 개(48\%), 그 이하인 경우가 13 개(52\%) 로 거의 비슷한 경향을 보였다.

학부 전공자의 비율을 대학원 유형에 따라 일반대학원과 특수 대학원으로 나누어 비교해 보았다. 학부 전공자 비율 $50 \%$ 를 기준 으로 나누었을 때 일반대학원은 $50 \%$ 이상인 경우가 9 개 중 6 개, 특 수대학원은 15 개 중 8 개였다. 가장 높은 비율을 보인 응답이 일반 대학원은 ‘학부 전공자가 전체에서 $71 \%$ 이상(3개)'이었던 데 비해 특수대학원은 '전체 중 30\% 이하(6개)'였다. 이를 통해 특수대학원 은 비전공자의 비율이 더 높은 경우가 그렇지 않은 경우보다 더 많 은 것으로 나타났다.

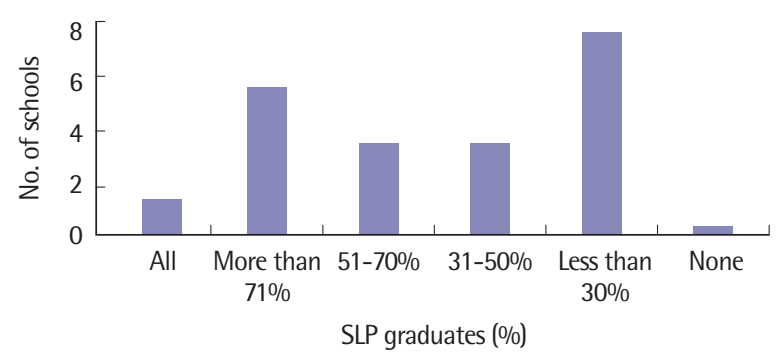

Figure 1. Percentages of speech-language pathology (SLP) graduates. 


\section{언어재활관찰실습 현황}

언어재활관찰실습 시행 여부

25 개 학교 중 관찰실습을 시행한다고 응답한 학교는 20 개 학교 (80\%)였고 5개 학교는 시행하지 않는다고 응답하였다. 시행하지 않 는다고 응답한 학교 중 2 개 학교는 재학생이 모두 학부 전공자여서 이미 학부 과정에서 관찰실습을 이수했기 때문에 개설하지 않는다 고 했다. 그 외의 3 개 학교는 관찰실습을 이수하지 않은 재학생의 경우 보충과목으로서 학부에서 이수하도록 조처하기 때문에 대학 원에서는 교과목을 개설하지 않는다고 보고했다. 관찰실습 시행 여부를 일반대학원과 특수대학원으로 나누어 비교한 결과 일반대 학원은 9 개 학교 중 5개가 ‘예’로 응답하였던 데 비해 특수대학원은 15 개 학교 모두 ‘예’로 응답하여 대학원 유형에 따라 차이가 있는 것으로 나타났다.

이후의 결과 분석은 전체 25 개 학교 중 관찰실습을 시행한다고 한 20개를 총수로 하여 진행할 것이다.

\section{언어재활관찰실습 교과목 개설}

관찰실습 교과목의 학점은 2 학점으로 개설되는 학교가 가장 많 았으나(10개, 50\%) 두 번째로 많이 응답한 3학점의 경우(8개, $40 \%)$ 와 큰 차이가 나지는 않았다. 1학점으로 개설된다고 학교가 1개(5\%) 였고 1개교는 학점에 대한 응답이 없었다. 시수는 2 시수가 8 개(40\%), 3 시수가 7개(35\%)였으며 1개교(5\%)가 6시수로 개설하고 있다고 응 답했다. 4 개교(20\%)는 교과목 개설 시수가 아니라 관찰실습 이수 시간인 30 시간으로 응답했다.

각 학교에서 보고한 학점 및 시수를 일반대학원과 특수대학원 으로 나누어 비교해보았다. 그 결과, 관찰실습을 시행한다고 보고 한 일반대학원 5 개 학교 중 4 개가 3 학점으로 개설한다고 응답했고 나머지 1 개는 2 학점으로 개설한다고 하였다. 시수는 3 시수가 3 개, 6 시수가 1 개였고, 1 개는 관찰실습 이수시간인 30 시간으로 응답했 다. 특수대학원은 전체 15 개 중 2 학점으로 개설하는 경우가 9 개로 가장 많았고 3 학점의 경우가 4 개, 1 학점이 1 개였다. 특수대학원 중 에서는 2 시수로 개설하는 학교가 8 개로 가장 많았고 3 시수가 4 개 였으며 3 개 학교는 관찰실습 이수시간 30시간으로 응답했다. 이를 통해 일반대학원은 3 학점 3 시수가, 특수대학원은 2 학점 2 시수로 개설되는 경우가 가장 많은 것을 알 수 있었다.

관찰실습이 개설되는 학기에 대한응답은 Figure 2에 제시되어 있다. 그림에서처럼 제 2 학기에 관찰실습 교과목을 개설하는 학교가 12 개 학교로 가장 많았으며 20 개 학교 중 17 개 학교 $(85 \%)$ 가 제 2 학 기 혹은 제 3 학기에 개설하는 것으로 나타났다.

관찰실습을 학기 중이나 방학 중 언제 실시하는지 질문했을 때

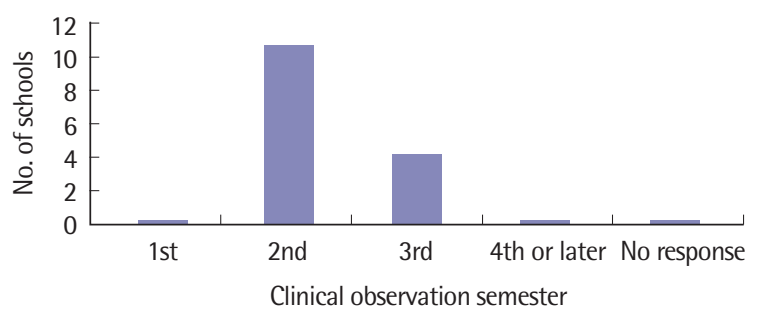

Figure 2. Semesters offering clinical observation.

대부분의 학교는 학기 중과 방학 중 둘 다 실시한다고 응답했다(16 개, $80 \%$ ) 학기 중에만 실시한다고 한 학교와 방학 중에만 실시한다 고 한 학교는 각 2 개였다(각 $10 \%$ ).

\section{언어재활관찰 실습생의 선정}

관찰실습생을 어떤 기준으로 선정하는지 복수응답을 허용한 상 황에서 응답하게 한 결과 가장 많이 응답한 경우는 '교과목 개설학 기에 해당되는 학생(17개, $85 \%$ '이었다. 그 외는 '필요학점을 이수한 학생(3개, $15 \%$ )', '선수과목을 이수한 학생(4개, 20\%)'이었다. 관찰실 습생 선정 시 성적 평점의 하한선이 있는지 질문했을 때 20 개 학교 모두 ‘아니오’라고 응답했다.

관찰실습을 면제해주는 경우가 있는지에 대한 질문에 6개 학교 $(30 \%)$ 가 '예’라고 응답했다. 이 6 개교 중 5 개교는 학부 전공자인 경 우, 1 개 학교는 학부 전공자이면서 언어재활사로 현장근무 중인 경 우 면제해준다고 응답했다. 장애인복지법 시행규칙에 따라 총 30 시 간 이상을 이수해야 하는 언어재활관찰의 시간을 줄여주는, 즉 감 면해주는 경우가 있는지에 대한 질문에 7개 학교(35\%)가 ‘예’라고 응답했고 12 개 학교(60\%)는 '아니오'라고 응답했으며 1개 학교는 응답하지 않았다. 감면 기준으로는 학부 전공자인 경우, 학부 전공 자이면서 자격증을 소지한 경우, 자격증 소지자이거나 학부에서 관찰실습 교과목을 이수한 경우의 응답이 있었고, 대개 이 기준에 해당되는 경우 $50 \%$, 즉 15 시간을 감면해준다고 응답했다.

관찰실습을 위해 미리 이수해야 하는 과목, 즉 선수과목이 있는 지에 대한 질문에 7 개 학교(35\%)가 '예’라고 응답했다. 이들이 응답 한 선수과목 목록 중에서는 의사소통장애개론(3개), 언어발달장 애(3개), 조음음운장애(2개), 언어발달(2개)이 복수의 응답을 얻었 고 1 개의 응답을 얻은 과목으로는 신경언어장애, 유창성장애, 음성 장애, 언어기관 해부생리, 의사소통장애 진단 및 평가, 언어재활현 장실무가 있었다.

\section{언어재활관찰실습생에 대한 사전교육 및 순회지도}

20 개 학교 모두 관찰실습을 위해 학생들에게 사전교육을 실시한 
다고 응답했고 그 방식으로는 모든 학교가 강의식으로 학생들에게 전달하는 것으로 보고했다. 관찰실습 교과목 진행 시 교과목 담당 교수가 기관을 순회하면서 지도하는지 질문했을 때에는 5 개 학교 (15\%)만이 순회지도를 시행한다고 응답했고 나머지 15 개 학교는 하지 않는다고 응답했다.

\section{직접관찰과 간접관찰의 비율}

언어재활관찰은 실습 대상자의 평가 및 중재 과정을 직접 대면한 상태에서 관찰하느냐, 혹은 동영상 등 시청각자료를 통해 간접적으 로 관찰하느냐에 따라 직접관찰과 간접관찰로 나뉜다. 직접관찰과 간접관찰의 비율에 대해 묻는 질문에 대한 응답을 Table 1에 정리 하였다.

Table 1에서 보는 것과 같이 직접관찰의 비율이 간접관찰보다 더 높은 학교가 20 개 학교 중 13 개(65\%)로 더 많았다. 모두 직접관찰 로 진행한다고 보고한 학교는 3 개교(15\%)로 나타났고 모두 간접관 찰로 진행한다고 한 학교는 없는 것으로 나타났다.

\section{언어재활관찰 실습 제공 기관 및 언어재활사}

관찰실습을 제공하는 기관을 묻는 질문에는 복수응답을 허용 하였다. 응답을 분석한 결과 전체 20 개 학교 중 17 개(85\%)가 사설치 료실(개인치료실)에서 관찰실습을 진행한다고 하여 가장 높은 비 율을 보였고, 그 다음으로는 종합병원 혹은 대학병원부속 언어치 료실이 14 개(70\%)로 나타났다. 개인병원부속 언어치료실에서 관찰

Table 1. Ratio of direct observation to indirect observation

\begin{tabular}{lc}
\hline & Number of schools (\%) \\
\hline $100 \%$ (direct observation all) & $3(15)$ \\
$\geq 71 \%$ (much more direct observation) & $7(35)$ \\
$51 \%-70 \%$ (a little bit more direct observation) & $3(15)$ \\
$31 \%-50 \%$ (a little bit less direct observation) & $6(30)$ \\
$\leq 30 \%$ (much less direct observation) & $1(5)$ \\
$0 \%$ (indirect observation all) & $0(0)$ \\
\hline
\end{tabular}

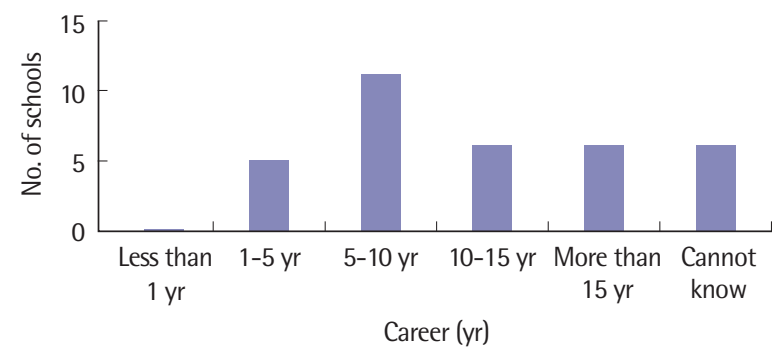

Figure 3. Careers of speech-language pathology providing clinical observations.
실습을 진행하는 학교가 8 개(40\%), 장애인종합복지관이 6개(30\%), 다문화가족지원센터가 4 개(20\%)로 보고되었다. 기타로 보고한 4 개 학교 $(20 \%)$ 중 3 개가 대학내 부설 언어치료센터에서 관찰실습을 진행한다고 했고 1 개 학교는 기타로 보고했으나 실습기관을 기록 하지는 않았다.

Figure 3은 관찰실습을 제공하는 언어재활사의 경력에 대한 응 답 분석결과이다. 이 경우는 하나의 학교마다 다수의 언어재활사 에게 실습을 제공받으므로 복수응답을 허용했다.

경력이 5-10년에 해당되는 언어재활사가 12 개(60\%)로 가장 많이 관찰실습을 제공하는 것으로 나타났고 10 년 이상의 경력자가 관찰 실습을 제공하는 경우도 전체 중 14 개(70\%)로 높은 비율을 보였다. 관찰실습 제공 언어재활사의 경력을 '파악하기 어렵다'고 응답한 경우도 7 개 학교에 달하는 것으로 나타났다.

관찰실습을 제공하는 언어재활사의 1 급 자격증 소지 비율을 조 사한 결과는 Table 2 와 같다.

관찰실습을 제공하는 언어재활사가 모두 1 급 자격증 소지자인 학교가 가장 많았고(7개, $35 \%)$ 이와 반대로 모두 2급 자격증 소지 자라고 응답한 학교는 없었다. $50 \%$ 이상이 1 급 자격증 소지자라고 응답한 학교가 13 개(65\%)여서 그렇지 않은 경우보다 훨씬 더 높은 비율을 보였다.

Table 2. Ratio of speech-language pathology certificate level 1 to level 2

\begin{tabular}{lc}
\hline & Number of schools (\%) \\
\hline $100 \%$ (level 1 all) & $7(35)$ \\
$\geq 71 \%$ (much more level 1 ) & $4(20)$ \\
$51 \%-70 \%$ (a little bit more level 1) & $2(10)$ \\
$31 \%-50 \%$ (a little bit less level 1$)$ & $0(0)$ \\
$\leq 30 \%$ (much less level 1$)$ & $2(10)$ \\
$0 \%$ (level 2 all) & $0(0)$ \\
Cannot know & $5(25)$ \\
\hline
\end{tabular}

Table 3. Types of communication disorders observed

\begin{tabular}{lc}
\hline & Number of schools (\%) \\
\hline Developmental language delay & $20(100)$ \\
Speech sound disorder & $20(100)$ \\
Fluency disorder & $16(80)$ \\
Neurogenic language disorder & $15(75)$ \\
Hearing impairment & $14(70)$ \\
Motor speech disorder & $13(65)$ \\
Voice disorder & $12(60)$ \\
Language development support for the children from & $4(20)$ \\
$\quad$ multicultural families & $1(5)$ \\
Others &
\end{tabular}




\section{언어재활관찰 실습 대상자 장애영역}

관찰실습을 통해 학생들이 관찰할 수 있는 장애영역에 대한 보 고는 복수응답을 허용하였다. 그 결과를 Table 3에 제시하였다.

20 개 학교가 모두 언어발달장애와 조음음운장애 대상자의 관찰 을 포함하고 있었고 다수의 학교가 유창성장애, 신경언어장애, 청 각장애, 마비말장애, 음성장애 대상자를 접할 기회를 제공하고 있 었다. 기타로 표시한 1 개 영역은 구개열 영역이었다.

\section{언어재활관찰실습 관련 평가}

관찰실습 실습생에 대한 평가는 실습기관의 기관장 혹은 언어 재활사와 교과목 담당교수가 공동평가하는 경우가 가장 많았다 (13개, $65 \%)$. 실습기관에서 전적으로 평가하는 경우는 2개(10\%), 교 과목 담당교수가 평가하는 경우는 5 개 학교(25\%)로 보고되었다.

관찰실습이 끝난 후 학생들의 만족도에 대해 평가하는지에 대한 질문에서는 ‘예’라고 응답한 경우가 9개(45\%), '아니오'라고 응답한 경우가 10 개(50\%)로 큰 차이를 보이지 않았으며 응답하지 않은 경 우가 1 개(5\%)였다. 만족도를 평가하는 경우 그 방법으로는 집담회 를 실시하는 경우가 3 개, 체크리스트로 평가하는 경우가 5 개, 기타 가 4 개였다. 기타에는 강의평가를 통해 판단하는 경우가 3 개였고 구두로 평가하는 경우 1 개가 포함되었다.

\section{언어재활관찰실습 진행 시 애로사항}

관찰실습을 진행하는 데 애로사항에 대해서 임의로 기록하도록 했다. 응답을 분석한 결과 가장 많은 어려움으로 언급된 내용은 '관 찰실습을 위한 기관섭외가 어렵다'(6개)였다. 이 외에 '대학원생들 의 일정과 실습기관이 원하는 일정을 맞추는 데 어려움이 있다', '대 학부설 혹은 종합병원의 경우 기관 자체의 내규 등으로 관찰 기회 를 제한하고 있다', '비전공자의 경우 대학원 2 학점 관찰시수만으로 는 조건을 충족시키기 어려워 방학에도 관찰시간을 채우도록 하고 있다', '객관적 평가가 어렵다', '다양한 장애군에 대한 고른 관찰이 어렵다', '지방대학의 경우 다른 지역으로 이동하는 데 시간이 많이 소요된다', '기관사용료나 실습경비의 충당이 어렵다, '실습기관의 현장 재활사들에게 관찰내용이나 형식에 대한 요구나 기대를 전달 하기 어렵다', '학생의 예의 및 품성 문제로 난처할 때가 있다' 등이 언급되었다.

\section{논의 및 결론}

본 연구는 대학원 언어치료학과 석사과정에서 이루어지는 언어 재활관찰실습의 현황을 파악하고자 대학원 언어재활관찰을 운영
하는 교원을 대상으로 온라인 설문조사를 실시하고 그 결과를 분 석한 연구이다. 전체 27 개 학교 중 25 개 학교에서 회신한 응답을 분 석한 결과를 간략히 요약하면 다음과 같다.

1. 설문에 응한 학교는 특수대학원에 속해있는 경우가 많았고 인 문사회계열에 속한 경우와 자연계열에 속한 경우는 비슷했다. 석사과정 안에 학부 전공자가 더 많은 경우와 더 적은 경우는 서로 비슷했는데 특수대학원은 비전공자 비율이 높은 경우가 더 많았다.

2.25 개 학교 중 20 개 학교가 언어재활관찰실습을 시행한다고 보 고하였다. 대학원 유형을 언급하지 않은 1 개 학교를 제외한 24 개 학교 중 일반대학원은 전체 9 개 학교 중 5 개 학교가 관찰실 습을 시행한다고 했고 특수대학원은 대학원 유형을 보고하지 않은 1 개 학교를 제외한 전체 15 개 학교가 모두 관찰실습을 시 행한다고 했다. 관찰실습 교과목은 대개 제 2 학기에 개설되었 고 방학과 학기의 구분 없이 지속되었다. 관찰실습 교과목의 개설은 일반대학원은 주로 3 학점 3 시수, 특수대학원은 2 학점 2시수로 개설되는 경우가 가장 많았다.

3. 관찰실습생은 교과목 개설학기에 해당되는 학생을 대상으로 주로 이루어졌는데 학부 전공자인 경우나 자격증을 소지한 경 우 관찰실습을 면제해주거나 감면해주는 학교가 많았다. 관찰 실습 시작 전에 모든 학교가 실습생에게 사전교육을 실시했으 며 일부 학교는 실습기간 중 순회지도를 한다고 했다.

4. 직접관찰과 간접관찰에 대해서는 이 둘을 모두 병행해서 진행 하는 경우가 많았으며 이런 경우 대개 간접관찰보다 직접관찰 의 비율이 더 높았다.

5. 관찰실습은 사설치료실이나 각종 병원부속 언어치료실, 장애 인종합복지관, 다문화가족지원센터에서 주로 이루어졌다. 관 찰실습을 제공하는 언어재활사의 경력은 5 년에서 10 년 사이 가 가장 많았고 1 급 자격증 소지자의 비율이 2 급 소지자보다 더 높았다.

6. 관찰실습 대상자의 의사소통장애 영역은 모든 학교가 언어발 달장애, 조음음운장애를 포함하고 있었고 대부분의 영역을 고루 관찰하도록 진행하고 있었다.

7. 관찰실습의 평가는 실습을 지도하는 기관장 및 언어재활사와 교과목 담당교수가 공동으로 평가하는 경우가 많았다. 관찰실 습 후 학생들의 만족도를 평가하는 학교와 그렇지 않는 학교의 비율은 서로 비슷했다.

8. 관찰실습 시 애로사항으로는 기관섭외의 어려움이 가장 큰 것 으로 나타났고 그 외 일정 조정의 어려움, 실습경비의 부담 등 이 언급되었다. 
관찰실습을 시행하는 학교는 설문에 응답한 25 개 학교 중 20 개 학교였고 5 개 학교는 시행하지 않는다고 보고했는데 이 5 개 학교는 모두 일반대학원에 포함되어 있었다. 특수대학원은 일반대학원과 달리 모든 개설학교가 관찰실습을 시행하고 있었는데 이는 특수대 학원 재학생 중 비전공자의 비율이 더 높기 때문인 것으로 판단된다.

일부 일반대학원에서 관찰실습을 시행하지 않는 이유로는 전원 학부 전공자인 이유도 있었지만 학제 내 학부가 있어 비전공자는 보충과목처럼 학부에서 관찰실습을 이수하게 하기 때문인 경우도 많았다. 이와 같이 학부와 대학원이 동시에 운영되는 학교는 비교 적 관찰실습 개설의 부담에서 비교적 자유롭다. 그러나 대학원만 개설되어있는 학교는 대학원 학제 내에서 실습을 해결해야 하므로 부담이 더 큰 것이 현실이다.

대부분의 학교가 제 2 학기나 제 3 학기에 관찰실습 과목이 개설되 는 경우가 많은데 이는 비전공자의 경우 모든 의사소통장애 영역 에 대한 수업을 아직 듣지 못한 시기일 확률이 높다. 관찰실습이 효 과적이기 위해서는 학생들의 충분한 사전준비가 필요한데 이를 위 해서 필요한 것으로 대두되는 것 중 하나가 선수과목의 필요성이 다. 이는 언어재활과 전공 학생들의 임상관찰실습 전에 선수교과 이수의 필요성을 강조한 Kim과 Lee (2015)나 Hwang 등(2012)의 연 구에서도 뒷받침되고 있다. Lee 등(2015)은 관련 전공지식의 부족 이 언어재활과 학생들의 실습불안을 높인다고 했다. 그러므로 선 수과목을 지정하거나 실습생들의 사전준비도를 파악할 수 있는 평 가를 시행하고 부족한 부분을 보완하는 과정을 통해 실습생들의 불안을 낮추고 실습효율성을 높일 수 있도록 해야 한다.

교과목 개설 시 2 학점으로 개설하느냐, 3 학점으로 개설하느냐는 대학원의 유형에 따라 달라질 수 있다. 연구결과에서 보았듯이 특 수대학원인 경우는 2 학점으로, 일반대학원으로는 3 학점으로 개설 되는 경우가 많았다. 이렇듯 대학원 관찰실습은 학과 및 학교 상황 의 영향을 많이 받는다. 예를 들어 학부 전공자의 비율이 높은 이유 가 신입생 선발 시 전공자의 비율을 학과가 주체적으로 결정한 결 과일 수도 있지만 학교 규정상 비전공자의 자격증시험 응시조건을 채워줄 정도로 많은 과목을 개설할 수가 없어 부득이하게 학부 비 전공자를 입학시키지 못해서일 수도 있다. 이것이 학부와 달리 대 학원의 관찰실습이 매우 다양하게 나타나는 주된 이유 중 하나이 다. 그러므로 각 학과가 학교의, 학과의 상황에 맞는 적절한 관찰실 습 교과과정 수립을 위해 노력해야 한다. 예를 들어 뒤에서 다시 언 급될 것이나주로 야간강의로 진행되는 경우가 많아 현장에서 언어 재활사로 근무 중인 재학생이 많은 특수대학원의 경우 주간에 이 루어지는 실습과 직장 근무를 어떻게 조율할 것인지 등에 대해 숙 고할 필요가 있다.
실습생이 직접 관찰실습기관을 방문하여 실습대상자와 치료실 안에서 직접 혹은 관찰실을 통해서 간접적으로 대면하며 실습을 진행하는 직접관찰은 다양한 측면에서 실습생에게 큰 도움을 준 다. 동영상으로는 전달할 수 없는 평가 및 중재 현장의 세밀한 면까 지 관찰할 수 있을 뿐 아니라 언어재활이 실제로 이루어지는 기관 의 모양, 구성, 분위기, 운영체계를 직접 확인할 수 있기 때문이다. 그러나 실습생들이 직접관찰을 하려면 실습생의 방문을 허용해주 는 기관을 섭외해야 하는데 이는 매우 어려운 일이다. 관찰실습을 진행하는 데 애로사항으로 가장 많이 지적한 것이 기관섭외의 어 려움이었다는 데에서도 잘 나타난다.

실습기관의 중요성은 다양한 연구에서 지적되었다. 다양한 학과 의 임상실습 만족도 조사 연구에서 실습기관에 대한 낮은 만족도 를 보고했는데 Kim과 Shin (2015) 그리고 Hwang 등(2012)은 언어 치료 전공학생들의 임상실습 만족도 연구에서 실습환경에서 실습 생의 만족도가 낮음을 지적했다. Park (2000)은 중등학교 가정과 교육실습에서도 실습기관 내 교생을 위한 공간 부족을 언급했고 Song과 Kim (2013)은 간호학과 실습생을 위한 실습기관의 지원이 부족한 데 대한 아쉬움이 있다고 했다. Kim과 Kang (2004)은 작업 치료학과 학생의 임상실습 시 실습기관과 대학과의 협동체계가 잘 이루어지지 않는다고 했는데 이는 실습기관의 실습에 대한 인식 부 족과 대학 담당교수의 노력 부족 때문이라고 지적했다. 이는 언어 치료학과에도 똑같이 적용될 수 있는 내용이다.

$\operatorname{Kim}$ 등(2007)은 예비 특수교사의 교육실습 시 실습 지도교사가 학생의 수준 및 특성을 파악하고 라포를 형성하는 데 미흡하였다 고 보고했다. 이에 대해 이들은 교육실습을 담당할 특수학교의 증 가 속도에 비해 예비 특수교사 양성 속도가 더 빨라 실습기관이 미 처 적절한 교육을 제공할 수 있는 여건을 마련하지 못하고 있는 것 이 문제를 유발한다고 했다. 이는 현재 예비 언어재활사의 교육여 건에서도 유사하게 나타나고 있는 현상이라고 볼 수 있다. 즉, 언어 재활관찰 실습 시 적절한 기관을 섭외하기 어려운 이유 중 하나는 실습을 제공할 만한 언어치료 및 재활기관이 충분치 않아서이기도 하다는 것이다. 언어치료기관이 집중되어있는 서울 및 경기지역 외 에 위치한 학교는 실습기관 선정의 어려움이 더 크다. 이를 해소하 기 위해 방학을 이용하여 서울 및 경기지역으로 관찰실습을 보내 기도 하나 여기에는 실습생 이동 경비에 대한 지원 문제, 안전 문제 등이 있어 이 또한 쉽지 않다.

Lee 등(2004)은 작업치료학과의 임상실습교육 시 임상실습기관 선정의 문제에 대해 지적하고 있는데 실습기관 확보가 시급하다 보 니 임상실습교육의 질적인 면에 소홀해질 수밖에 없다고 했다. 우리 가 실습기관이라고 하는 기관은 원래 내원하는 의사소통장애 대 
상자의 평가 및 중재를 목적으로 하는 치료실이기 때문에 실습이 첫 째 목적이 아니다. 그럼에도 불구하고 관찰실습을 받아줄 경우 실습기관은 그로 인한 업무량의 증가, 일부 치료 대상자 및 보호자 들의 불만, 실습생의 태도 문제 등을 감수해야 한다. 관찰실습을 담 당하는 학과 교수들은 이를 충분히 인지하고 있기 때문에 관찰실 습을 위한 다양한 요구를 하기 어려운 경우가 많은데 이는 관찰실 습 진행의 애로사항 중에도 포함되어 있었다. 또한 관찰실습을 제 공하는 언어재활사의 경력 혹은 소지한 자격증의 급수에 대해 파 악하지 못했다고 응답한 학교가 20 개 중 $1 / 3$ 에 가까운 것도 이와같 은 맥락에 기인한다고 볼 수 있다.

Lee SE (1997)는 간호교육기관을 섭외하는 데 전임교원의 역량 에 전적으로 의존하는 문제점에 대해 언급했다. 언어재활 관련 학 과에서도 전임교원의 인맥에 의지하여 실습기관을 섭외하는 경향 이 우세하며, 전임교원이 임상경력 혹은 강의경력이 많지 않은 경 우 실습기관을 섭외하기가 쉽지 않다. 이로 인한 문제를 해결하고 자 아직 임상경험이 많지 않은 졸업생에게 의지하는 경우도 많은데 이런 경우 다양한 의사소통장애 영역, 다양한 평가 및 중재방법을 접할 기회가상대적으로 적어진다.

관찰실습 진행의 애로사항 중에는 실습생의 일정과 기관이 요구 하는 일정을 맞추기 어렵다는 내용도 있었다. 학부의 언어재활관찰 실습에서도 수업과 관찰실습 일정의 중복으로 인한 문제가 생길 수 있다. 대학원도 물론 수업과 겹치는 문제로 일정을 정하기 어려 운 점도 있으나 학부와 달리 직장 근무 일정 때문에 곤란한 경우가 생기는 경우도 많다. 즉, 대학원 재학생 중에는 자격증을 가지고 현 장에서 근무하고 있는 경우가 많은데 대개 수업이 없는 때 근무 일 정을 정하기 때문에 실습 일정과 겹치는 경우가 종종 생기는 것이 다. 이런 경우 대부분의 학교가 최대한 실습생의 일정을 배려해주 지만 이로 인해 이수 시간을 채우는 것이 늦어지거나 다양한 경우 를 관찰할 기회가 적어지거나 더 많은 기관을 섭외해야 할 필요가 생길 수도 있다.

관찰실습에서 배운 내용은 이후 진단 및 재활실습으로 이어지기 때문에 질적, 양적으로 충분치 못한 관찰실습은 후의 진단 및 재활 실습에도 영향을 미친다. 관찰실습기관 섭외의 어려움은 거의 모든 학과가 겪는 어려움이므로 언어재활사협회 혹은 언어치료학과 교 수협의회의 차원에서 지원책이 필요하다. 학과에서 실습제공 기관 에 기관사용료의 명목으로 소정의 실습비를 제공하고 있으나 이는 매우 적은 금액으로 관찰실습을 위해 실습제공 기관 및 재활사가 제공하는 시간, 노고를 보상하기에는 턱없이 부족하다. 그러므로 관찰실습을 제공하는 언어재활사에게 실습제공시간을 보완교육 의 인센티브로 인정해주는 등의 타당하고 적절한 지원책이 필요하
다. 또한 언어치료기관 네트워크를 통해 관찰실습기관을 조직적, 질 적 관리를 도모하는 방법도 모색해볼 수 있다. 예를 들어 지역별로 관찰실습을 제공하는 기관을 파악하여 긴밀한 네트워크를 수립하 고 해당지역의 대학 혹은 대학원에서 실습제공 기관의 질적 개선 및 지식 공유를 위한 다양한 공부모임, 세미나 혹은 워크숍 등을 개 최하는 것도 한 방법이라고 볼 수 있겠다.

음성장애나 신경언어장애 대상자, 기질적 말소리장애 대상자는 대학병원이나 종합병원에서 접하는 경우가 대부분인데 현재는 이 러한 대형병원에서의 실습 기회가 계속 감소하고 있다. 이는 개별 병원의 비협조에도 원인이 있겠으나 대학병원 종합평가 등 정책적 측면과도 관련이 있으므로 해결이 쉽지 않다. 이런 경우 직접관찰 보다 간접관찰을 적극적으로 활용하는 것도 한 방법이다. 이때 병 원 소속 언어재활사와의 연결고리를 찾기 어려운 경우 적절한 언어 재활사의 섭외가 어려울 수도 있으므로 임상실습 관련 네트워크 수 립으로 인한 협조체계 구축이 필요하다.

본 연구는 대학원 석사과정에서 이루어지는 언어재활관찰실습 전반에 대한 현황을 설문조사를 통해 개관해보았다. 그러나 이는 기초적 현황에 대한 연구로 추후에 더 많은 후속연구가 이루어져 야 한다. 이미 학부생을 대상으로 설문연구가 이루어진 바 있는 언 어재활관찰실습에 대한 만족도나 실습으로 인한 스트레스나 불안 에 대한 연구뿐 아니라 자격증을 소지한 현장 언어재활사로서 직 장과의 병행으로 생기는 제반문제에 대한 연구도 필요하다. 관찰실 습을 진행하는 데 중요한 역할을 하는 실습환경, 실습경비 등에 대 해 보다 더 세밀한 연구도 필요하다. 사실 본 연구는 대학원 전체를 대상으로 했어도 총수가 30 개가 안되기 때문에 설문조사로 연구하 기에는 충분하지 않은 부분도 포함하고 있다. 이를 위해 질적연구 의 방법을 도입해보는 것도 추후연구로서 의미 있을 것으로 판단된 다. 이와 같이 다양한 연구와 다각도적인 노력을 통해 효과적인 대 학원 언어재활관찰실습이 이루어지도록 노력해야 한다.

\section{REFERENCES}

Hwang, H. J., Choi, S. Y., Kim, S. Y., \& Lee, M. K. (2012). Students' and graduates' satisfaction with clinical observation and clinical treatment practice in the department of speech \& language rehabilitation. Journal of the Daegu Health College, 32, 211-220.

Kim, H. Y., Park, K. O., Lee, T. S., \& Yoo, J. Y. (2007). A survey on practicum for pre-service special education teachers. Journal of Special Education: Theory and Practice, 8, 419-443.

Kim, J. K., \& Kang, D. H. (2004). The survey on the perception of occupation- 
al therapy faculty on the clinical fieldwork. Journal of Korean Society of Occupational Therapy, 12, 91-103.

Kim, S. H., \& Lee, J. Y. (2015). A comparative study of the need for prerequisite subjects for clinical observation between speech therapy students and supervisors. Journal of Speech-Language \& Hearing Disorders, 24, 9-16.

Kim, S. J., \& Lee, S. H. (2009). The development and evaluation of a clinical skill-based curriculum model for speech therapy. Korean Journal of Communication Disorders, 14, 413-428.

Kim, S. Y., \& Shin, M. S. (2015). A study of the satisfaction and teaching efficiency of clinical practice of students majoring in speech-language pathology. Journal of Speech-Language \& Hearing Disorders, 24, 17-31.

Kim, S. Y., Kim, C. H., Song, J. Y., Ahn, D. H., \& Chae, J. B. (2004). An investigation of factors which influence physical therapy students' satisfaction with their clinical practice. Physical Therapy Korea, 11, 71-84.

Koo, H. Y., \& Im, H. S. (2013). Comparison of factors influencing satisfaction of clinical practice between associate and bachelor nursing students. Journal of the Korea Contents Association, 13, 311-321.

Korean Association of Speech-Language Pathologists. (2017). Standards for the certification in speech-language pathology. http://www.kasla.or.kr/

Kwon, S. B., Kim, S. J., Pae, S. Y., Yoon, H. R., Hwang, M. A., \& Shin, M. S. (2010). A basic study for department of speech pathology certification with a focus on the educational environment. Journal of Speech \& Hearing Disorders, $19,1-23$.

Lee, H. J., Goh, D. S., Kim, H. Y., Yang, S. O., Yoon, S. N., Lim, N. Y., .. \& \& Han, Y. R. (2002). Actual condition of practice in home care nursing training program. Journal of Korean Academic Society of Home Care Nursing, 9, 4653.

Lee, H. S., Bae, B. J., \& Park, M. H. (2005). Research on actual conditions of clinical training in departments of dental technology. Journal of the Daegu Health College, 25, 85-98.

Lee, M. J., Kim, K. M., Lee, J. S., Lee, T. Y., Kang, D. H., Lee, K. S., \& Yoo, E. Y. (2004). The current fieldwork affiliation status of the occupational therapy education programs in Korea. Journal of Korean Society of Occupational Therapy, 12, 105-117.

Lee, M. S., Park, H., \& Park, C. H. (2015). A study of the correlation between self-efficacy and practice-related anxiety of students majoring in speech rehabilitation. Journal of Speech-Language \& Hearing Disorders, 24, 147158.

Lee, O. J., Shin, J. A., \& Jung, S. H. (2010). A study on the clinical practice in ophthalmic optics. Journal of the Korean Ophthalmic Optics Society, 15, 319328.

Lee, S. E. (1997). A study on the actual condition of practical apprenticeship training for university (college) nursing education and developing reform measure in Korea. Journal of Korean Academic Society of Nursing Education, 3, 226-245.

Lee, S. H., Kim, S. Y., \& Kim, J. A. (2004). Nursing students' image of nurse and satisfaction with clinical practice. Journal of Korean Academy of Nursing Administration, 10, 219-231.

Lee, S. J. (1997). Satisfaction level on practice lesson of student in health and industry departments. Korean Journal of Health Education and Promotion, $14,159-169$

National Law Information Center. (2017a). Act on welfare of persons with disabilities. http://www.law.go.kr/lsSc.do?menuId=0\&p1=\&subMenu=1\& nwYn=1\&section=\&tabNo=\&query=\%EC $\% 9 \mathrm{E} \% \mathrm{~A} 5 \% \mathrm{EC} \% 95 \% \mathrm{~A} 0 \% \mathrm{EC} \%$ 9D\%B8\%EB\%B3\%B5\%EC\%A7\%80\%EB\%B2\%95\#undefined

National Law Information Center. (2017b). Enforcement of the Act on welfare of persons with disabilities. http://www.law.go.kr/lsSc.do?menuId=0\& $\mathrm{p} 1=\&$ subMenu $=1 \& \mathrm{nw} \mathrm{Yn}=1 \&$ section $=\& \operatorname{tabNo}=\& q u e r y=\% \mathrm{EC} \% 9 \mathrm{E} \% \mathrm{~A} 5$ \%EC\%95\%A0\%EC\%9D\%B8\%EB\%B3\%B5\%EC\%A7\%80\%EB\%B2\%95\# undefined

Park, E. S. (2000). The survey of teaching practice and the factors of satisfaction on teaching practice in home economics education. Journal of Korean Home Economics Education Association, 12, 129-143.

Song, J. H., \& Kim, M. W. (2013). Study on clinical education for nursing in hospitals in Korea. Journal of Korean Academic Society of Nursing Education, 19, 251-264.

Yoo, A. R., \& Kim, M. J. (2009). Practicum reality and improvement direction of secondary special education. Nazarene Review, 13, 67-90.

Yoon, S. S., So, M. H., \& Namkung, S. (1989). A study on the real management of experimental-practice and spot-practice at department of food and nutrition of junior college in Korea. Korean Journal of Food and Nutrition, 2, 61-72. 
Appendix 1. 대학원 석사과정 임상실습 설문지

안녕하십니까? 조선대학교 언어치료학과 표화영입니다.

바쁘신 와중에 설문에 응해주셔서 대단히 감사합니다.

본 설문지는 대학원 석사과정에서 시행되는 관찰실습(언어재활관찰)과 임상실습(언어진단실습 및 언어재활실습)이 학과마다 매우 다양하게 이루어지고 있는 현 시 점에서 그 현황을 파악하고자 제작되었습니다.

설문에 대해 사실 그대로의 답변을 빠짐없이 기록해 주시기 부탁드립니다.

응답해 주신 내용은 분석을 위해서만 사용되며 학교 및 학과정보의 외부 노출은 절대로 없을 것입니다.

다시 한 번 협조에 감사드리며 문의사항이 있으시면 언제든 아래 연락처로 연락 주시기 바랍니다.

조선대학교 언어치료학과 표화영

\section{I. 배경정보}

1. 귀 학과가 소속된 대학원의 유형은 무엇입니까?
1) 일반대학원 - 2번으로 가십시오.
2) 특수대학원이나 기타대학원 - 1-1번으로 가십시오.

1-1. 소속 대학원의 이름을 써주십시오(예: 보건재활대학원).

2. 귀 학과의 계열은 다음 중 어디에 해당됩니까?
1) 인문사회계열
2) 자연계열
3) 기타(계열 이름을 써주십시오.)

3. 귀 학과의 전체 석사과정생 중 학부 전공자의 비율은 어느 정도입니까?

1) 모두 학부전공자 (학부 전공자 $100 \%)$

2) 전체 중 학부 전공자가 $71 \%$ 이상 (모두는 아니나 비전공자보다 훨씬 많은 편이다.)

3) 전체 중 학부 전공자가 $51 \%-70 \%$ (비전공자에 비해 절반 조금 넘는다.)

4) 전체 중 학부 전공자가 $31 \%-50 \%$ (비전공자에 비해 절반 조금 안 된다.)

5) 전체 중 학부 전공자가 $30 \%$ 이하 (전혀 없는 것은 아니나 비전공자보다 휠씬 적은 편이다.)

6) 모두 학부 비전공자 (비전공자 $100 \%$ )

\section{I. 언어재활관찰}

4. 귀 학과는 석사과정 학생에게 언어재활관찰(이하, 관찰실습)을 시행합니까?

$\begin{array}{ll}\text { 1) 예 - 5번으로 가십시오. } & \text { 2) 아니오 - 4-1번으로 가십시오. }\end{array}$

4-1. 관찰실습을 시행하지 않는 이유를 간략히 써주십시오.

5. 관찰실습을 시작하는 학기는 언제입니까?
1) 제 1 학기
2) 제2학기
3) 제3학기
4) 제4학기 혹은 그 이후

6. 관찰실습을 시행하는 시기는 언제입니까?
1) 학기 중
2) 방학 중
3) 학기 중 및 방학 중 둘 다

7. 관찰실습 교과목의 학점 및 시수는 어떻게 됩니까? 학점 - / 시수 -

8. 관찰실습의 실습생은 어떻게 선정하십니까? 해당사항에 모두 체크해주십시오.
1) 교과목 개설 학기에 해당하는 학상
2) 필요한 학점을 이수한 학생
3) 선수과목을 이수한 학생
5) 기타(간략히 써주십시오.)
4) 실습이수 능력 검증 시험을 통과한 학생

9. 관찰실습을 면제해주는 경우도 있습니까?
1) 예 - 9-1번으로 가십시오.
2) 아니오 - 10번으로 가십시오.

9-1. 관찰실습 면제의 기준은 무엇입니까? 간략히 써주십시오.

10. 관찰실습의 이수시간을 줄여주는(감면해주는) 경우가 있습니까?
1) 예 - 10-1로 가십시오.
2) 아니오-11번으로 가십시오. 
10-1. 관찰실습 감면의 기준은 무엇입니까? 간략히 써주십시오.

11. 관찰실습을 위한 선수과목이 있습니까?

1) 예-11-1번으로 가십시오. 2) 아니오-12번으로 가십시오.

11-1. 선수과목의 과목명을 써주십시오.

12. 관찰실습을 위한 성적 평점의 하한선이 있습니까?

1) 예 -12-1번으로 가십시오. 2) 아니오-13번으로 가십시오.

12-1. 성적 평점 하한선을 써주십시오.(예: 직전 학기까지 총평점 2.0 이상)

13. 관찰실습 전에 사전교육(오리엔테이션)을 실시하십니까?

1) 예-13-1번으로 가십시오. 2) 아니오-14번으로 가십시오.

13-1. 사전교육은 어떻게 실시하십니까?
1) 강의식으로 교육
2) 이메일 등으로 유인물 전달
3) 기타(간략히 써주십시오)

14. 직접관찰(학생이 기관 방문)과 간접관찰(재활사가 학교 방문해서 동영상으로 설명)의 비율은 대략 어느 정도입니까?

1) 모두 직접관찰로 진행 (직접관찰 100\%)

2) 전체 중 직접관찰이 $71 \%$ 이상 (모두는 아니나 간접관찰보다 훨씬 많은 편이다.)

3) 전체 중 직접괓찰이 $51 \%-70 \%$ (간접관찰에 비해 절반 조금 넘는다.)

4) 전체 중 직접관찰이 31\%-50\% (간접관찰에 비해 절반 조금 안 된다.)

5) 전체 중 직접관찰이 $30 \%$ 이하 (전혀 없는 것은 아니나 간접관찰보다 횔씬 적은 편이다.)

6) 모두 간접관찰로 진행 (간접관찰 $100 \%$ )

15. 관찰실습을 제공하는(실습생을 파견하는) 기관의 종류는 무엇입니까? 해당사항에 모두 체크해주십시오.
1) 사설 치료실
2) 장애인복지관
3) 개인병원 부속 치료실
4) 종합병원 혹은 대학병원 부속 치료실
5) 다문화 가족지원센터
6) 기타(기관의 종류를 써주십시오)

16. 간접관찰 혹은 직접관찰을 제공해주는 언어재활사의 경력은 대략 어느 정도 됩니까? 해당사항에 모두 체크해주십시오.
1) 1 년 미만
2) 1 년 이상-5년 미만
3) 5 년 이상-10년 미만
4) 10 년 이상-15년 미만
5) 15 년 이상
6) 파악하기 어렵다.

17. 간접관찰 혹은 직접관찰실습을 제공해주는 언어재활사의 1급 자격증 소지자의 비율은 대략 어느 정도 됩니까?

1) 모두 1급 자격증 소지자 (1급 소지자 $100 \%)$

2) 전체 중 1급 자격증 소지자가 $71 \%$ 이상 (모두는 아니나 2급 소지자보다 횔씬 많은 편이다.)

3) 전체 중 1급 자격증 소지자가 $51 \%-70 \%$ (2급 소지자에 비해 절반 조금 넘는다.)

4) 전체 중 1급 자격증 소지자가 31\%-50\% (2급 소지자에 비해 절반 조금 안 된다.)

5) 전체 중 1급 자격증 소지자가 $30 \%$ 이하 (전혀 없는 것은 아니나 2급 소지자보다 훨씬 적은 편이다.)

6) 모두 2급 자격증 소지자 (2급 소지자 $100 \%)$

7) 파악하기 어렵다.

18. 관찰실습 과정에서 관찰하는 영역은 무엇입니까? 해당사항에 모두 체크해주십시오.
1) 언어발달장애
2) 조음음운장애
3) 신경언어장애
4) 마비말장애
$\begin{array}{ll}5) \text { 유창성장애 } & 6) \text { 음성장애 }\end{array}$
7) 청각장애
8) 다문화 가정 언어발달 지도

9) 기타(해당 영역을 써주십시오)

19. 관찰실습 교과목 담당교수가 실습기관을 순회하면서 학생들을 지도하십니까?
1) 예
2) 아니오

20. 관찰실습 평가는 누가 하십니까?
1) 실습기관 기관장(실습제공 언어재활사 포함)
2) 교과목 담당교수
3) 기관장 및 담당교수 둘 다
4) 기타(간략히 써주십시오)

21. 관찰실습 후 학생들의 만족도 평가를 실시하십니까?

1) 예 - 21-1번으로 가십시오.

2) 아니오 - 22번으로 가십시오.

21-1. 만족도를 평가하는 방법은 무엇입니까? 해당사항에 모두 체크해주십시오.
1) 집담회
2) 체크리스트 작성
3) 기타(간략히 써주십시오)

22. 관찰실습을 진행하는 데 애로사항이 있으면 써주십시오. 


\section{국문초록}

\section{언어치료학과 대학원 석사과정의 언어재활관찰실습 현황 연구 표화영}

조선대학교 언어치료학과

배경 및 목적: 학부에 비해 국내 대학원에서 이루어지는 언어재활관찰실습에 대한 연구는 극히 드물다. 이에 본 연구는 대학원 석사과 정의 언어재활관찰실습 현황에 대해 조사하여 그 실태를 파악하고 이를 근거로 대학원 관찰실습 방법의 개선방안을 찾아보고자 하였 다. 방법: 석사과정에 언어치료(재활)학과가 개설된 27 개 대학원의 언어재활관찰실습 운영 담당교원에게 22 개 문항으로 이루어진 설문 지를 온라인을 통해 배포하였다. 이중 25 개교의 응답이 회수되었고 그 결과의 빈도 및 백분율을 분석하였다. 결과: 전체 25 개교 중 20 개 교가 언어재활관찰실습을 진행하고 있었으며 학부 전공자나자격증 소지자의 경우 관찰실습을 면제해주거나 감면해주고 있었다. 간접 관찰보다 직접관찰의 비율이 대체로 더 높았으며 실습은 주로 사설치료실이나 각종 병원 부속 치료실, 장애인종합복지관에서 이루어 졌다. 관찰실습을 제공하는 언어재활사는 2급 자격증 소지자보다 1급 소지자가 더 많았고 경력은 5-10년 사이가 가장 많았다. 실습생은 언어발달장애, 조음음운장애, 유창성장애 등 다양한 장애영역의 대상자를 접하는 것으로 나타났다. 관찰실습의 애로사항으로는 기관 섭외의 어려움, 일정을 정하는 데의 어려움 등이 지적되었다. 논의 및 결론: 언어재활관찰실습을 진행하는 다수의 학교가 실습생으로 하여금 다양한 의사소통장애와 다양한 기관을 접할 수 있도록 노력하고 있다. 이를 위해 학과 차원의 노력은 물론 학회 및 협회의 다양 한 지원책 모색이 필요하다.

핵심어: 언어재활관찰, 언어치료학과, 대학원, 설문조사

이 논문은 2014년도 조선대학교 학술연구비의 지원을 받아 연구되었음.

\section{참고문헌}

구현영, 임형석(2013). 학제별 간호대학생의 임상실습 만족도에 미치는 영향 비교. 한국콘텐츠학회논문지, 13,311-321.

국가법령정보센터(2017a). 장애인복지법. http://www.law.go.kr/lsSc.do?menuId $=0 \& p 1=\&$ subMenu $=1 \& n w Y n=1 \& s e c t i o n=\&$ tabNo = \&query = \%EC\%9E\%A5\%EC\%95\%A0\%EC\%9D\%B8\%EB\%B3\%B5\%EC\%A7\%80\%EB\%B2\%95\#undefined

국가법령정보센터(2017b). 장애인복지법 시행규칙. http://www.law.go.kr/lsSc.do?menuId $=0 \& p 1=\& s u b M e n u=1 \& n w Y n=1 \& s e c t i o n=\& \operatorname{tabNo}=$

\&query $=\% \mathrm{EC} \% 9 \mathrm{E} \% \mathrm{~A} 5 \% \mathrm{EC} \% 95 \% \mathrm{A0} \% \mathrm{EC} \% 9 \mathrm{D} \% \mathrm{~B} 8 \% \mathrm{~EB} \% \mathrm{~B} 3 \% \mathrm{~B} 5 \% \mathrm{EC} \% \mathrm{~A} 7 \% 80 \% \mathrm{~EB} \% \mathrm{~B} 2 \% 95 \#$ undefined

권순복, 김수진, 배소영, 윤혜련, 황민아, 신명선(2010). 언어치료학과 학과인증제를 위한 기초 연구: 교육환경 중심으로. 언어치료연구, 19, 1-23.

김선엽, 김지혁, 송주영, 안덕현, 채정병(2004). 물리치료학 전공 학생들의 임상실습 만족도에 영향을 미치는 요인 조사. 한국전문물리치료학회지, 11,

71-84.

김선희, 이지윤(2015). 언어재활전공 학생들과 임상감독자들 간의 언어임상관찰 선수교과에 대한 필요도 비교 연구. 언어치료연구, 24, 9-16.

김수진, 이수향(2009). 언어치료 임상실습 교육모형 개발 및 적용. 언어청각장애연구, 14, 413-428.

김시영, 신명선(2015). 언어치료 전공학생의 임상실습 만족도 및 교수효율성 연구. 언어치료연구, 24, 17-31.

김진경, 강대혁(2004). 작업치료(학)과 교수를 대상으로 한 임상실습에 관한 연구. 대한작업치료학회지, 12, 91-103.

김호연, 박경옥, 이태수, 유재연(2007). 예비특수교사의 교육실습 운영 실태 분석 및 인식 조사. 특수교육저널: 이론과 실천, 8, 419-443.

박은숙(2000). 중등학교 가정과 교육실습 실태 및 교육실습 만족도에 영향을 미치는 요인. 한국가정과교육학회지, 12, 129-143.

송지호, 김미원(2013). 간호학 임상실습교육 실태 조사. 한국간호교육학회지, 19, 251-264.

유애란, 김명자(2009). 중등특수교육 실습 실태와 개선방향. 나사렛 논총, 13, 67-90.

윤성식, 소명환, 남궁석(1989). 전문대학 식품영양과의 실험실습 및 현장실습 운영실태에 관한 연구. 한국식품영양학회지, 2, 61-72. 
이명순, 박현, 박찬희(2015). 언어재활과 학생들의 자기효능감과 실습불안에 대한 상관관계 연구. 언어치료연구, 24, 147-158.

이미자, 김경미, 이재신, 이택영, 강대혁, 이경식, 유은영(2004). 작업치료 교육에 있어서 임상실습 교육 현황 분석. 대한작업치료학회지, $12,105-117$.

이성은(1997). 우리나라간호교육기관의 현장실습교육 실태 파악 및 개선방향 모색에 대한 연구. 한국간호교육학회지, 3, 226-245.

이순자(1997). 보건 및 공업계열 학생의 실습만족도에 관한 비교연구. 보건교육건강증진학회지, 14, 159-169.

이순희, 김숙영, 김정아(2004). 간호학생의 간호이미지와 임상실습만족도. 간호행정학회지, 10, 219-231.

이옥진, 신진아, 정세훈(2010). 안경광학과 임상실습 실태에 관한 연구. 한국안광학회지, 15, 319-328.

이화식, 배봉진, 박명호(2005). 치기공과 임상실습교육 실태조사. 대구보건대학논문집, 25, 85-98.

이흥자, 고덕순, 김혜영, 양순옥, 윤순녕, 임난영, 한경자, 한영란(2002). 가정간호 교육과정에서의 실습 실태. 가정간호학회지, 9, 46-53.

한국언어장애전문가협회(2017). 자격증 규정. http://www.kasla.or.kr/

황하정, 최선영, 김시영, 이무경(2012). 언어재활과 재학생 및 졸업생들의 임상관찰 및 임상치료 실습에 대한 만족도. 대구보건대학 논문집, 32, 211-

220. 